Kritchanchai, D., \& MacCarthy, B. L. (1999). Responsiveness of the order fulfilment process. International Journal of Operations \& Production Management, 19(8), 812-833.

\title{
Responsiveness of the order fulfilment process
}

\author{
Duangpun Kritchanchai and Bart L. MacCarthy
}

University of Nottingham, Nottingham, UK

\begin{abstract}
This paper discusses evidence from field studies undertaken to investigate the responsiveness of the order fulfilment process in a number of companies. The evidence is analysed in the context of the literature on responsiveness and related areas such as time-based competition. Similarities and differences are analysed across a number of industrial sectors with respect to order fulfilment processes and the interpretation and significance of responsiveness. Generic factors that influence different types of companies are identified. Four components of responsiveness - stimuli, awareness, capabilities and goals - emerge from an analysis of the literature. The field and case study evidence allows the development of more precise definitions and descriptions of each of these components. The study also allows a generic responsiveness framework to be developed that incorporates both strategic and operational viewpoints. The need for more field studies on responsiveness is noted. More work is advocated on the assessment and measurement of responsiveness and on developing appropriate responsiveness interventions, particularly with respect to the order fulfilment process.
\end{abstract}

Keywords Responsiveness, Order processing, Process management, Operations management

\section{Introduction}

The provision of resources and systems capable of meeting variable demands from customers is a central question in operations management. Developing appropriate order fulfilment processes that can cope with fluctuations in both volume and variety poses many problems. Increasingly, the order fulfilment process is viewed as a key business process for achieving and maintaining competitiveness and is frequently the subject of re-engineering initiatives. Developing more responsive order fulfilment processes is generally recognised as being desirable. However, although its importance is recognised, the concept and meaning of responsiveness are difficult to define or specify. The study presented in this paper addresses responsiveness of the order fulfilment process. It aims to make the concept of responsiveness more tangible and to contribute to the development of appropriate levels of responsiveness for different types of company.

The approach taken is to identify those elements and themes that recur either explicitly or implicitly in the literature on responsiveness and related areas such as time-based competition. These are used to guide a field study investigating responsiveness of the order fulfilment process. Observations are reported from a number of companies in Thailand with supporting evidence from companies in the UK and case studies in the literature. Similarities and differences across industrial sectors are analysed with respect to order fulfilment processes, the interpretation and significance 
Kritchanchai, D., \& MacCarthy, B. L. (1999). Responsiveness of the order fulfilment process.

International Journal of Operations \& Production Management, 19(8), 812-833.

of components of responsiveness and generic factors that influence overall characteristics. This enables us to define and describe more accurately the components of responsiveness emerging from the literature. The study also allows us to develop a framework for responsiveness in manufacturing enterprises that incorporates both strategic and operational viewpoints. Implications of the research and proposals for further work are discussed.

\section{Relevant literature}

Here we briefly review papers from the literature that have influenced our understanding of, and perspectives on responsiveness and the order fulfilment process. We first consider literature on responsiveness and then consider literature related to the order fulfilment process.

\section{Responsiveness literature}

The term 'responsiveness' has been used in research literature from a number of management areas including time-based competition, business process reengineering, flexible manufacturing, agile manufacturing and mass customization. Much of the literature has focused on how to improve aspects of responsiveness in manufacturing industry.

Frey (1988) proposes a set of performance measures as a tool to help managers identify the actions needed to provide customers with products that are superior to the competitors. This set comprises performance measures for cost, quality and responsiveness. Responsiveness is seen as the ability of a department within a firm to respond to changes in customer needs or in market conditions.

Stalk (1988) focuses on time-based competition and refers to responsiveness as one of the outcomes from implementing a time-based approach. He recommends that system procedures be simplified and computer-based technology be improved. An example from Toyota is given where a company-developed computer system links its sales people directly to the factory scheduling operation, enabling several levels of the sales and distribution function to be bypassed. Hence, the flow of information is speeded up, decision making is improved and, as a result, the company can improve system responsiveness.

In their book, Stalk and Hout (1990) state that companies are obtaining remarkable results by focusing their organisations on responsiveness. They imply that the need for responsiveness comes from competing in a time-based environment. The authors give examples of ways to increase responsiveness by replenishing stock at retailers more often than competitors, filling an order faster than competitors and having less process time than competitors. Using these methods, a company will be able to offer more choice in a faster time. Interestingly they suggest that responsiveness should apply only to the most important customers.

Azzone and Masella (1991) focus on time-based competition. They first deal with the impact of time and responsiveness on value, noting that better responsiveness may cement customer loyalty, improve differentiation and increase the value perceived by customers. Customers are willing to choose a particular 
Kritchanchai, D., \& MacCarthy, B. L. (1999). Responsiveness of the order fulfilment process.

International Journal of Operations \& Production Management, 19(8), 812-833.

company's products when what is requested can be supplied in a relatively short time. On the other hand, when response time lengthens a customer will look around for better prices or better products. If better responsiveness is achieved, Azzone and Massella believe this can lead to premium pricing and higher market share and, as a result, competitive advantage.

Barclay et al. (1996) is the only paper where responsiveness is explicitly defined and a model of responsiveness established. They define responsiveness as the ability to react purposefully and within an appropriate timescale to significant events, opportunities or threats (especially from the external environment) to bring about or maintain competitive advantage. A responsiveness model is proposed composed of six factors \pm drivers, timescale, strategy, focus, providers and capability. In our view these six factors can be grouped under three themes: first, the events or influencing factors to which the company has to respond; second, the ability to react to and/or predict events in order to manage, control and take advantage; and third, the approaches to achieve responsiveness. The authors also suggest that the responsiveness capabilities appropriate for any company depends on its own environment. They provide a good overview of aspects relevant to responsiveness but focus only on the new product development process.

Bozart and Chapman (1996) focus on time-based competition. They discuss make-to-stock, make-to-order, assemble-to-order and engineer-to-order environments and state that in some environments, particularly engineer-toorder, the more appropriate perspective is one that focuses on improving the responsiveness of manufacturing to specific customer requirements. They also recommended that highly flexible processes and workers, and excess resources are the most appropriate tactics as the means to achieve responsiveness in the engineer-to-order environment. Ultimately, combining all these practices leads to a shrinking in cycle times and the ability to respond quickly to changes in demand level or customer requirements.

Sin and Hoon (1996) reviewed the literature on time-based competition. The essence of time-based competition involves compressing time in every phase of the product creation and delivery cycle. They believe that only time-based competitors will have the ability to dominate their industries. Becoming a time-based firm can increase responsiveness to customers and the ability to meet customer demands and to respond quickly to changing consumer needs.

The literature cited above covers the main areas commonly referred to in discussions of responsiveness. Table 1 summarises the main emphases of each paper. A number of issues and themes recur either explicitly or implicitly. Frey (1988), Stalk and Hout (1990), Azzone and Masella (1991), Barclay et al. (1996), Bozart and Chapman (1996) and Sin and Hoon (1996), highlight the need for, and the factors driving, responsiveness. These issues can be summarized as:

- The factors that drive a system to be responsive and the need to be aware of them. 


\section{Table 1. Responsiveness literature}

\begin{tabular}{|c|c|c|c|}
\hline Author & $\begin{array}{l}\text { Responsiveness } \\
\text { drivers/needs for } \\
\text { responsiveness }\end{array}$ & $\begin{array}{l}\text { Methods to achieve } \\
\text { responsiveness }\end{array}$ & $\begin{array}{l}\text { Benefits of } \\
\text { responsiveness }\end{array}$ \\
\hline Frey (1988) & $\begin{array}{l}\text { The changes in } \\
\text { customer needs or } \\
\text { in market } \\
\text { conditions }\end{array}$ & - & - \\
\hline Stalk (1988) & - & $\begin{array}{l}\text { Simplify } \\
\text { procedures in the } \\
\text { system and } \\
\text { improve decision } \\
\text { making and } \\
\text { computer based } \\
\text { technology }\end{array}$ & - \\
\hline $\begin{array}{l}\text { Stalk and } \\
\text { Hout (1990) }\end{array}$ & $\begin{array}{l}\text { The need for more } \\
\text { competitive } \\
\text { advantage through } \\
\text { time }\end{array}$ & $\begin{array}{l}\text { Replenishing the } \\
\text { stock in its store } \\
\text { more often, filling } \\
\text { an order faster } \\
\text { than competitors, } \\
\text { and reducing } \\
\text { process time }\end{array}$ & $\begin{array}{l}\text { Fill an order faster } \\
\text { with less } \\
\text { processing time } \\
\text { than competitors }\end{array}$ \\
\hline $\begin{array}{l}\text { Azzone and } \\
\text { Masella } \\
\text { (1991) }\end{array}$ & $\begin{array}{l}\text { The requirement } \\
\text { occurs when } \\
\text { response time } \\
\text { lengthens and } \\
\text { customer look } \\
\text { around for better } \\
\text { prices of products }\end{array}$ & - & $\begin{array}{l}\text { Achieving } \\
\text { competitive } \\
\text { advantage }\end{array}$ \\
\hline $\begin{array}{l}\text { Barclay } \\
\text { et al. (1996) }\end{array}$ & $\begin{array}{l}\text { The } \\
\text { responsiveness } \\
\text { drivers: customers, } \\
\text { suppliers, } \\
\text { competitors and } \\
\text { global factors }\end{array}$ & $\begin{array}{l}\text { Responsiveness } \\
\text { strategy and } \\
\text { factors affecting } \\
\text { responsiveness } \\
\text { capability }\end{array}$ & $\begin{array}{l}\text { Brings about or } \\
\text { maintains } \\
\text { competitive } \\
\text { advantages }\end{array}$ \\
\hline $\begin{array}{l}\text { Bozart and } \\
\text { Chapman } \\
\text { (1996) }\end{array}$ & $\begin{array}{l}\text { The need to } \\
\text { respond to } \\
\text { changing customer } \\
\text { requirements }\end{array}$ & $\begin{array}{l}\text { The process } \\
\text { should be } \\
\text { sufficiently flexible }\end{array}$ & $\begin{array}{l}\text { Shrink cycle time } \\
\text { to respond quickly } \\
\text { to changes in } \\
\text { customer } \\
\text { requirements }\end{array}$ \\
\hline $\begin{array}{l}\text { Sin and } \\
\text { Hoon (1996) }\end{array}$ & $\begin{array}{l}\text { The need for } \\
\text { responsiveness in } \\
\text { time based } \\
\text { competition to } \\
\text { respond to } \\
\text { changing customer } \\
\text { needs }\end{array}$ & $\begin{array}{l}\text { Compressing time } \\
\text { in every phase of } \\
\text { the product } \\
\text { creation and } \\
\text { delivery cycle }\end{array}$ & $\begin{array}{l}\text { Meet customer } \\
\text { demand and } \\
\text { responding quickly } \\
\text { to changing } \\
\text { customer needs }\end{array}$ \\
\hline
\end{tabular}


Kritchanchai, D., \& MacCarthy, B. L. (1999). Responsiveness of the order fulfilment process.

International Journal of Operations \& Production Management, 19(8), 812-833.

Stalk (1988), Stalk and Hout (1990), Barclay et al. (1996) and Bozart and Chapman(1996), focus on methods to achieve or facilitate responsiveness. Different papers propose different methods to develop responsiveness to particular drivers. These issues can be summarized as:

- The need to have different abilities to respond to different drivers and the need for capabilities implying more than just the existence of technical abilities.

Stalk and Hout(1990), Azzone and Masella (1991), Barclay et al. (1996) and Sin and Hoon (1996), point out the benefits of achieving responsiveness. The benefits identified vary in different papers, particularly with respect to what companies aim to achieve and over what timescale. This reflects the fact that different targets may be appropriate for different firms depending on their environment. These issues can be summarized as:

- The need to establish goals for responsiveness appropriate to the business and operational environment of a particular firm.

Against this background we identify four components of responsiveness: stimuli - the responsiveness drivers; awareness - to be aware of the drivers and what is needed to respond; capabilities - the ability to respond to different drivers; goals the targets or objectives of each firm in its environment. These components have guided the fieldwork studies discussed later in this paper. Using field evidence we define and described them more precisely later in the paper, along with a framework for responsiveness that uses them. The issue of goals raises the question of strategy and its impact on the direction and constraints of responsiveness for any firm. The framework developed later incorporates a strategic dimension. However, the main emphasis of this paper is on the operational level, in particular the order fulfilment process.

\section{Order fulfilment process literature}

Unfortunately, there are few sources in the literature discussing the details of the order fulfilment process explicitly. However, the order fulfilment process is implied in the work of a number of authors. Some discuss the activities that relate to order processing and some imply the order fulfilment process in the context of achieving or implementing responsiveness. Here we identify some important contributions and clarify our interpretation of order fulfilment.

Fry (1990) defined manufacturing lead time as the difference between when an order is released to the shop and when it is available to the customer. He states that tremendous advantages such as increased flexibility and responsiveness, can be realised with shorter manufacturing lead times. Bozart and Chapman (1996) presented a contingency view of time-based competition for manufacturing companies. One of the time-based competition strategies proposed focuses on how to improve flexibility and responsiveness of business processes to changing customer requirements. They distinguish between online and off-line activities in the process. The former covers all the activities that can be started only when a customer order 
Kritchanchai, D., \& MacCarthy, B. L. (1999). Responsiveness of the order fulfilment process.

International Journal of Operations \& Production Management, 19(8), 812-833.

arrives and ends when the order is delivered to the customer. The latter activities are those that can be completed prior to the arrival of a specific customer order such as design, procurement and component manufacturing. Interestingly their view is that responsiveness and flexibility are not the desired performance characteristics for both on-line and off-line activities. They recommended that responsiveness and flexibility are appropriate tactics to focus on for on-line activities.

Daugherty and Pitman (1995) conducted exploratory research investigating what firms are doing to make their operations more flexible and to allow them to become more responsive to their customers. Their study focused on time management and responsiveness was observed in relation to manufacturing lead time and distribution lead time. The manufacturing lead time encompasses order preparation time, queue time, set-up time, run time, move time and inspection time; distribution time includes the time required for order transmission, order processing, order preparation and transit.

When viewing the responsiveness of the order fulfilment process there is some fuzziness about where to place the boundaries of an investigative study. The view we take accords with Shapiro et al. (1992) who argued that focusing on the full order management cycle offers significant opportunities and competitive advantages. From the perspective of responsiveness, a comprehensive view of the order fulfilment process is necessary, including all stages of planning and processing up to receipt of an order by the customer. This view has guided our thinking in the fieldwork with respect to the investigation of responsiveness of the order fulfilment process.

\section{Gathering evidence}

Approach

Using the background on responsiveness and order fulfilment processes gained from the literature, a field study was conducted in order to:

- investigate the general understanding and interpretation of the four components of responsiveness highlighted above - stimuli, awareness, capabilities and goals;

- observe the order fulfilment process in a range of manufacturing environments;

- investigate the interpretation of components of responsiveness in practice across order fulfilment process activities.

The field study focused on the order fulfilment process of seven companies in Thailand. In addition supporting evidence was gained from a workshop involving six UK companies and from case study evidence in the literature.

Eight case studies were obtained from semi-structured interviews conducted with seven companies in Thailand. The companies vary in size, product range and volume. The sample included five large size companies (with more than 3,000 employees), two of which are Thai-owned companies, the others being American, British and 
Kritchanchai, D., \& MacCarthy, B. L. (1999). Responsiveness of the order fulfilment process.

International Journal of Operations \& Production Management, 19(8), 812-833.

and Japanese. The products of the large companies include: canned fruit for both the local and European markets; oil and gas for industry and distributors; consumer products for local markets; electronic components for the manufacture of computer hardware. The other two companies are small to medium sized local Thai companies. The products include: industrial gas supplies for hospitals and the steel industry; machined parts for local and foreign market; and specialised machinery for industry. The latter company generated two case studies \pm one for machined parts and one for specialised machinery.

This broad range of companies provided a basis to investigate order fulfilment processes across a spectrum of product types and industry sectors. The interview questions were set in order first to observe the activities along the order fulfilment process and second to investigate the existence and interpretation of the responsiveness components in each case study. The first aspect was addressed by interviewing managers at a reasonably senior level, typically in the following departments: sales and marketing, material purchasing, production planning and scheduling, and the warehouse function. The interview questions explored:

- The activities in pre-order stage, i.e. all the activities conducted before orders arrive such as sales forecasting, facility and capacity planning, raw material planning and stock planning.

- The overall company business, the nature of the industry and its characteristics.

- The activities in the order processing stage, i.e. all the activities conducted after order arrival including order receipt, due date assignment, order prioritisation, product design and order confirmation, short term production planning, production scheduling, inventory management and product delivery.

The second aspect was addressed by obtaining the company's view on responsiveness and its components. The components of responsiveness - stimuli, awareness, capabilities and goals - were implied by asking questions on:

- factors, issues and problems that drive the company to respond and their awareness of the need to respond;

- the methods they use to respond;

- why they respond and their desired outcomes.

Narrative descriptions were made of the order fulfilment process for each case study in Thailand. Pre-order activities, order processing activities and order transmission activities were observed, taking into account each department's view. Particular attention was paid to the activities undertaken before an order arrives and the reaction of each relevant department to customer orders at the order entry stage. The links 
Kritchanchai, D., \& MacCarthy, B. L. (1999). Responsiveness of the order fulfilment process.

International Journal of Operations \& Production Management, 19(8), 812-833.

and co-operation between departments for facilitating customer orders were also noted.

Further evidence on the issues of responsiveness in order fulfilment was gained by analysing cases of six UK companies presented at a workshop on 'Responsiveness in Manufacturing' held in the UK (MacCarthy and McFarlane, 1998). Five of the companies are large with products including food, beverages, cycles, automobiles and steel. The sixth company is an SME, designing and manufacturing specialist-conveying systems.

Case studies from the literature are also used. These come from various industries in both the manufacturing and service sector, including machinery (Upton, 1994), food (Van Donk, 1998), metal dies, electronic power supplies, textiles (Noori and Radford, 1995) and the retail and airline sectors (Slack et al., 1998). Collecting case study evidence of this type, from a number of sources, may result in evidence of variable quality. Although most of the cases selected have some limitations in the information provided, they offer useful contributions to our understanding of responsiveness. Our principal objective in collecting and analyzing this category of evidence is to observe the interpretation and importance of responsiveness components in different environments.

\section{Observations from the Thai company study}

The Thai case studies show both differences and similarities in the order fulfilment process and the importance of the responsiveness components. The canned fruit company has a similar order fulfilment process to both the consumer products manufacturer and the machine parts products of the machinery manufacturer. These products tend to be fairly standard in terms of specification, design or model and the demand tends to fluctuate by volume and variety across the ranges. Customer demand can be forecast and production begins before customer orders enter the system. They also have safety stocks of finished products to serve customer demand as needed.

Within one company different types of order fulfilment process can occur. This is exemplified by the machinery company. For machined parts, production is triggered by forecast demand, whereas production of specialised machinery is triggered by the arrival of actual orders. Safety stocks of specialised machinery are never kept. In the oil and gas companies it is necessary to keep replenishing the stock of finished product \pm the typical policy being to maintain maximum safety stock levels at all times. This is driven by the nature of the industry (monopoly), by the nature of the product (standard specifications with a limited product range) and by the potential impact of a stockout on customers. Most products are subject to a continuous level of demand, closely matching forecasts. As a result, such companies intentionally produce most products to maintain maximum safety stock levels. The concept of safety stock also applies in the canned fruit, machined parts and consumer products companies. However, it is not feasible in these 
Kritchanchai, D., \& MacCarthy, B. L. (1999). Responsiveness of the order fulfilment process.

International Journal of Operations \& Production Management, 19(8), 812-833.

cases to continuously maintain safety stock levels for every kind of product because of high demand fluctuations in both volume and variety across the ranges.

The degree of importance of departments in the order fulfilment process varies across the Thai case study companies. The sales departments in the canned fruit, consumer products and machined parts manufacturer tend to give a lot of attention to fluctuations in volume and variety of customer demands. The level of safety stock requires significant attention for the oil and gas companies. The specialised machinery manufacturer spends much time on the design and quotation stages. These differences in emphasis are clearly due to the different problems faced within the order fulfilment process in each environment.

The types of problem or stimuli that occur in one company may mean very little or may never occur in another company. For example, volume fluctuations in customer demand drive the canned fruit, consumer products and machine parts manufacturer to frequently adjust the production plan. In the specialised machinery manufacturer, on the other hand, volume fluctuations in demand occur over a much longer time horizon and production is geared up for specific orders. Although both groups are affected by variety fluctuations, the canned fruit, consumer products and machine parts manufacturer tend to experience variety in demand across the product ranges whereas variety fluctuation occurs in terms of customised demand in the specialised machinery manufacturer.

Moreover, the same stimuli may impact differently on different companies. In oil and gas production, line or machine breakdown has a very major impact with potentially disastrous consequences. If continuous flow production stops for any significant length of time safety stocks will be quickly used up and stockouts will occur, due to the continuous demand for most products. Line or machine breakdown in the canned fruit, consumer products and machine parts companies may have a serious impact but the likelihood of disastrous consequences are lower, because there is not continuous demand for safety stock for every kind of product.

As the stimuli on the companies are different or have different levels of impact, they need to be aware of, and implement, different capabilities to respond to the particular stimuli. The canned fruit, consumer products and machined parts companies tend to have good relationships with suppliers in order to cope with the fluctuations in volume of raw materials required as demand varies for finished products. The specialised machinery manufacturer also tends to have good relationships with its suppliers but in this case to ensure that they can be supplied with the very specific type and quality of raw material or components they need. Thus they emphasise specific technical capabilities in their suppliers rather than volume capability. The companies tend to have different goals underpinning their responsiveness, influenced by their products, customer demand, the market they are in and their position in that market. The canned fruit, consumer products 
Kritchanchai, D., \& MacCarthy, B. L. (1999). Responsiveness of the order fulfilment process.

International Journal of Operations \& Production Management, 19(8), 812-833.

and machine parts companies attempt to fulfil customer orders with their standard specification products, whereas the specialised machinery manufacturer attempts to fulfil customer demand exactly against the customer specification. Moreover, it is clear from our sample that companies tend to select and operate in the market segments in which they are confident that they can respond competitively.

Overall, the sample companies in Thailand were able to answer the interview questions comfortably, indicating that the postulated components of responsiveness are recognized in practice. The companies were also able to contribute to our understanding of the meaning and importance of each of the components in different environments.

\section{Supporting evidence from UK companies}

Further evidence on the issues of responsiveness in order fulfilment processes was gained by analysing cases of six UK companies presented at a workshop on 'Responsiveness in Manufacturing' held in the UK (MacCarthy and McFarlane, 1998). The observations from these companies broadly agree with the observations from the companies in Thailand with respect to the characteristics of their order fulfilment processes.

Differences are apparent among the companies in their order fulfilment processes and the importance of the responsiveness components. The food and beverage companies tend to forecast demand in advance and production is triggered based on the forecast. The steel company tends to produce and hold intermediate semi-finished stocks with customer demand triggering production of steel products rolled and finished from stock items. The specialist conveying system company must wait for customer orders and their specifications before they start production.

The types of stimuli in these companies vary. Fluctuations in demand volumes and variety across product ranges tend to be the major factor in the food and beverage companies. In the steel industry, volume and variety demand fluctuations also occur but the fluctuations in demand variety are much more of a problem than in food and beverage production. This is because the steel industry has both variety in demand across ranges and customised demand. Predicting customer needs for finished steel products is more difficult. However its customised demand is still based on standard raw materials and semi-finished products. This has consequential effects on the requirements planning for materials and the production of intermediate stock items. As customisation is an essential part of the business for the specialist conveying system company, variety in customer demand is expected and is experienced at a higher degree of customisation than in the steel industry. The differences in stimuli lead to differences in the capabilities needed by the companies. The food and beverage companies focus on forecasting and production planning. In steel the emphasis is placed on capacity planning and real time scheduling. The specialist conveying system company has attempted to develop quick response in the design and quotation stage by developing a product configurator for this purpose. 
Kritchanchai, D., \& MacCarthy, B. L. (1999). Responsiveness of the order fulfilment process.

International Journal of Operations \& Production Management, 19(8), 812-833.

In terms of goals, the food and beverage companies attempt to provide and fulfil customer demand in terms of volume and variety. The steel company and the conveying system company try to achieve customer needs in terms of customer specifications.

\section{Case studies from the literature}

Further supporting evidence was gained from a number of case studies in the literature. The case studies noted below are convincing on the emergence of the components of responsiveness. In each case, stimuli, awareness, capabilities and goals are evident. However, the interpretation of these components varies in some cases. Upton (1994) gives an example of a machinery company and identifies the factors that drive it to respond - unpredicted customer demand and cheaper prices of competitors. Van Donk (1998) studied the food processing sector and noted that there are a number of changes affecting the industry. He summarised the causes as being due to changes in consumer preferences and supply chain restructuring by many retailers. The change in consumer preferences is causing an increase in the range of packaging sizes, in the number of products as well as in the number of new product introductions. When the machinery company is compared with companies in the food sector, it is apparent that these external stimuli are driving companies to develop different abilities to respond. The machinery company attempts to provide flexibility, the ability to control excessive inventory and the capability of machine tools and workers, while the food manufacturer is aiming at faster stock replenishment, delivering a greater variety of products and shortening cycle times.

On the other hand, there are groups of companies where stimuli, awareness and ability to respond occur in a similar manner with similar responses. Noori and Radford (1995) give examples of three manufacturing companies - in metal dies, in electronic power supplies and in the textile industry. Each of these three companies has a very wide variety of products with a wide range of components and materials. Stimuli come from the very wide range of products and drive the companies to respond by having general purpose, flexible, highly technical equipment, operational flexibility, and, importantly, by reducing design cycle time.

It is also noticeable that each of the three companies above has capabilities to respond that are specific to itself. The metal dies company establishes a particular team for each job. The team is responsible for planning and executing the job. This is to guarantee the accuracy and workability of the product and the reliability of the promised delivery date. The electronic power supplies company aims to reduce customer lead-time. Thus, they tend to reduce transport distance between processes, reduce setup or changeover time and integrate suppliers and customer into a "seamless" organisation. The textile company focuses on holding excess manufacturing capacity which can be activated as the need arises. This is because the company has adopted a philosophy of making only what the customer wants, in the quantity needed and at the time required. This can be explained by the 
Kritchanchai, D., \& MacCarthy, B. L. (1999). Responsiveness of the order fulfilment process.

International Journal of Operations \& Production Management, 19(8), 812-833.

fact that, although all three have similar stimuli, they have different goals, different types of products and different customer demand characteristics. Moreover, the stimuli affect these three companies to different degrees.

It is also important to note cases where companies limit their responsiveness, i.e. not responding to every customer demand, need or requirement. For instance, a large retailer (Slack et al., 1998) tends to limit customer buying power by stocking only a limited range of goods. This also happens with an example in the airline industry (Slack et al., 1998) where the strategy has been to compete on price with no meal or fixed seat provided. The company states that its service does not suit everyone but those who do buy a ticket at least get what they want and expect. Thus, although many companies across industry and business sectors desire responsiveness, it can be restricted by a particular company's business and market strategy.

\section{Analysis}

In analysing the evidence from the eight Thai and the six UK companies a number of aspects were taken into consideration including the characteristics of the order fulfilment processes, the type and range of stimuli, capabilities and goals observed, and the interpretation of the components of responsiveness. Established practices and planned change programmes were also viewed as important because they provide evidence of awareness of the need to have, or to develop specific response capabilities. Analysis of the similarities and differences across the sample allowed us to partition the companies into four groups. This type of approach is a form of content analysis (Easterby et al., 1991). Although it has limitations, and exceptions can always be identified in large organisations, clear similarities within groups, and clear differences between groups are apparent. Any one company may of course show differences across its product lines. The inclusion of companies in the groups below relates to the main product lines we were investigating. The characteristics of the four groups are discussed below.

\section{Group I}

This group includes the canned fruit, consumer products, food, beverage and machined parts companies. They tend to have standard specifications in design, models, sizes and other variants. The normal customer expectation is that demand will be met quickly when needed. Customers are usually supplied from stock or 'off-the-shelf. In many instances customers can go elsewhere if demand is not met. The stimuli mainly come from demand fluctuations in volume and variety across a product range. This group relies heavily on accurate forecasting to trigger production. The capability to absorb fluctuating demand is needed in order to be able to supply and satisfy customers and this is the primary goal in terms of order fulfilment. This causes many difficulties in raw material and production planning. Absorbing fluctuations in demand requires the capabilities to adjust capacity, adjust production levels and especially labour plans. Flexible workforces are needed in 
Kritchanchai, D., \& MacCarthy, B. L. (1999). Responsiveness of the order fulfilment process.

International Journal of Operations \& Production Management, 19(8), 812-833.

order to facilitate demand fluctuations. High levels of co-ordination are needed between raw materials purchasing, planners, sales and warehousing.

Group II

This group includes the three oil and gas companies. They produce highly standardised products that tend to have fixed compositions such as gas and oil production. This kind of company tends to be in a dominant or even a monopoly position and customers usually have to stick with them. Many customers have long-term contracts and demand levels tend to be close to forecasts. The goal of this continuous flow production is to produce to stock, maintaining safety stock at a pre-determined level at all times in order to serve demand with high reliability. The outflow rate of the stock is predictable. The inflow rate of the stock must be highly reliable to supply the outflow rate all the time. Factors that cause obstacles in maintaining stock levels, such as line/ machine breakdown, are considered as being very serious.

Delivering products to customers is a key aspect of order fulfilment in this sector as it accounts for a significant proportion of cycle time and there are usually numerous constraints making it difficult. Thus issues such as truck scheduling are a primary problem especially in high demand periods/seasons. Key capabilities for order fulfilment are the provision of adequate capacity for storage, facilitating production to enable the maintenance of stock levels, coordination between plants in order to rotate stock availability to respond to breakdowns, and the management of truck scheduling and delivery systems. Sharing information on production rates, stock holding levels and distribution levels are essential to ensure product availability and on-time delivery.

\section{Group III}

This group includes the steel, cycles and automotive companies. They produce a wide range of finished products. The products are customised to specification. They are manufactured and/or assembled from a range of standard intermediate stock items or semi-finished products. The finished products tend to have a higher degree of customisation than products in group I. This group of companies tends to want to minimise the holding of safety stock of finished products. The production system can be viewed in two stages: the first stage is to produce semi-finished products for stock in advance. The demand for semi-finished products is within a limited range and is forecastable. At the second stage production is triggered mostly by specific customer orders. Also included in this group are companies, such as the electronics components company, that customise from a limited range of raw materials and/or components. In this case the first stage can be viewed as the provision of raw materials and/or components and again production is triggered by actual orders in the second stage.

The stimuli for this group can also be considered in two stages. In the first stage, they face the same problem as the companies in group I or II. However the actual 
Kritchanchai, D., \& MacCarthy, B. L. (1999). Responsiveness of the order fulfilment process.

International Journal of Operations \& Production Management, 19(8), 812-833.

orders that trigger production at the second stage tend to be less predictable and variability in demand may have a significant impact. Adequate capacity and effective scheduling need to be provided to cope with unpredictable orders. This is especially the case where the production of semi-finished products needs some of the same facilities as the production of finished products. This group of companies requires good relationships with customers, in particular fully understanding their needs. Real-time scheduling is often required in the second stage to ensure that production resources are deployed effectively. Maintaining appropriate levels of raw material and semi-finished safety stock is important and needs frequent, often daily review. Effective coordination is needed between raw material planners and production planners and schedulers at the first stage and the second stage. These capabilities are necessary to achieve the goal of successfully supplying unpredictable variety in demand for finished products.

\section{Group IV}

This group includes the machinery and specialist conveying system company. The companies in this group produce fairly customised products. They differ from companies in group III as they have less opportunities to keep buffer stocks of raw materials or produce semi-finished product in advance. The degree of customisation means that products tend not to be repeatable and customers tend not to have repeatable demand. A customer order must be obtained before production can begin. Some orders may be rejected as being technically infeasible or unprofitable. The stages of design, quotation and confirmation have to be completed before a final specification is set. Customer orders tend not to change or fluctuate once the orders are placed. If changes are made then costs are borne by the customer. Thus the goal here is to provide customers with the product that meets their specifications, on time. Important capabilities are effective and efficient design, quotation and negotiation stages. Accurate and reliable information is essential for this area. Co-ordination between project design teams and production is also crucial to ensure quality, to meet required specifications and achieve on-time delivery. Many of the companies in this group will have specialist engineering expertise, often in industrial machinery. In some cases there may be opportunities to improve responsiveness by adopting a group III approach, i.e. customising from a basic product range.

In addition to partitioning companies into groups based on shared characteristics it is also valuable to analyse the generic factors that have placed companies in specific groups and that may influence the need for, and approach to responsiveness. Our analysis of potential factors indicates that the two principal differentiators are the nature of the product and the nature of customer demand. Two other important factors are the mechanism that triggers production and how customer demand is met. All of these factors are inter-related and, of course, any one firm may show differences across its product lines. We discuss these factors below and describe their influences in the groups above. 
Kritchanchai, D., \& MacCarthy, B. L. (1999). Responsiveness of the order fulfilment process.

International Journal of Operations \& Production Management, 19(8), 812-833.

Nature of product. This factor includes volume and variety, degree of standardisation or customisation, and extent of product range. It tends to be the major factor underlying differences in order fulfilment processes and differences in the degree of importance of the components of responsiveness. From the case studies, three classes of product may be distinguished on the standardisation/ customisation spectrum. First, in groups I and II, product ranges tend to have standard specifications from which the customer choice is made. Second, in group III, products tend to be specified or selected by the customer from a limited range of raw materials, components, options or designs. Third, in group IV, products are specified by the customer with, potentially, an unlimited range of raw material, components and designs. The nature of the product produced also has a close relationship with the nature of customer demand.

Nature of customer demand. The primary issue here is the nature of variation in demand. This includes volume fluctuations, variety fluctuations across product ranges, variety fluctuation within a product range, customised demand, occurrence of unexpected and non-repeatable demand, and whether demand can be forecast reliably. The nature of the product, the nature of the industry and its structure may influence the types of variation in demand. Companies in group I, typically have demand fluctuations in volume and variety across product ranges. Companies in group II tend to have demand that may be accurately forecast. For companies in group III, where customers specify products from standard raw materials and components, demand fluctuations tend to be in volume and variety both across product ranges and within a product range. For companies in group IV with fully customised products, unexpected and non-repeatable demand tends to occur. The nature of customer demand has an impact on how production is triggered.

Production triggering. We distinguish between three types of environments. In the first environment production is triggered primarily by forecasts. This tends to occur in companies in group II. In the second environment production is largely triggered by customer orders. This tends to occur in companies in groups III and IV. In the third environment a mix of forecasting and actual orders triggers production. This tends to occur in companies in group I where some mix of both policies will usually operate. The production triggering mechanism is related to how demand is actually met.

Meeting customer demand. Here we distinguish between meeting customer demand immediately it occurs and the situation where a customer must wait for demand to be met once an order is placed. Typically, if production is triggered by forecasting, such as the companies in group I and II, then customers can have demand satisfied 'off-the-shelf. But in the companies in groups III and IV, where production is triggered by direct customer orders, due dates must be established for product delivery.

Table II summarises the principal points from the above analysis. It shows the characteristics of each of the four groups of companies in terms of nature of product, nature of demand and the four responsiveness characteristics. It is apparent from the analysis above that the need for, and approach to, responsiveness differs across 


\section{Table 2. Groups of companies differentiated by nature of product, nature of demand and responsiveness characteristics}

\begin{tabular}{|c|c|c|c|c|}
\hline Characteristics & Group I & Group II & Group III & Group IV \\
\hline $\begin{array}{l}\text { (1) Nature of product } \\
\text { Components }\end{array}$ & $\begin{array}{l}\text { Mostly fixed } \\
\text { specification } \\
\text { and standard } \\
\text { components }\end{array}$ & $\begin{array}{l}\text { Mostly fixed } \\
\text { specification } \\
\text { and standard } \\
\text { components }\end{array}$ & $\begin{array}{l}\text { Standard } \\
\text { pattern but } \\
\text { components can } \\
\text { be varied } \\
\text { within } \\
\text { company's } \\
\text { ranges }\end{array}$ & $\begin{array}{l}\text { Can be both } \\
\text { standard and } \\
\text { customised } \\
\text { components }\end{array}$ \\
\hline Design & $\begin{array}{l}\text { Company- } \\
\text { design products } \\
\text { (can be like } \\
\text { group III } \\
\text { occasionally) }\end{array}$ & $\begin{array}{l}\text { Company- } \\
\text { design products } \\
\text { (can be like } \\
\text { group III } \\
\text { occasionally) }\end{array}$ & $\begin{array}{l}\text { Customer- } \\
\text { design but } \\
\text { within company } \\
\text { design ranges }\end{array}$ & $\begin{array}{l}\text { Customer- } \\
\text { designed } \\
\text { products }\end{array}$ \\
\hline $\begin{array}{l}\text { Customer expectations } \\
\text { from products }\end{array}$ & $\begin{array}{l}\text { For common- } \\
\text { use which } \\
\text { should be } \\
\text { available on- } \\
\text { shelf all time }\end{array}$ & $\begin{array}{l}\text { For common- } \\
\text { use but must } \\
\text { be available } \\
\text { when needed }\end{array}$ & $\begin{array}{l}\text { For common/ } \\
\text { special use }\end{array}$ & $\begin{array}{l}\text { For special } \\
\text { tasks }\end{array}$ \\
\hline Process & $\begin{array}{l}\text { Flow line, rigid } \\
\text { route, mostly } \\
\text { one product for } \\
\text { one line }\end{array}$ & $\begin{array}{l}\text { Continuous } \\
\text { flow line }\end{array}$ & $\begin{array}{l}\text { Mix model flow } \\
\text { line, flexible } \\
\text { and rigid routes }\end{array}$ & $\begin{array}{l}\text { Project, } \\
\text { multiple route }\end{array}$ \\
\hline $\begin{array}{l}\text { (2) Demand } \\
\text { Degree of } \\
\text { customization }\end{array}$ & Low & Low & $\begin{array}{l}\text { High but within } \\
\text { company } \\
\text { limitations }\end{array}$ & High \\
\hline Degree of fluctuation & $\begin{array}{l}\text { High in volume } \\
\text { and variety } \\
\text { across ranges }\end{array}$ & $\begin{array}{l}\text { Can be high } \\
\text { but demand } \\
\text { forecast is } \\
\text { highly reliable }\end{array}$ & $\begin{array}{l}\text { High in volume } \\
\text { and variety } \\
\text { both across } \\
\text { range and } \\
\text { customized } \\
\text { demand }\end{array}$ & $\begin{array}{l}\text { High in } \\
\text { customized } \\
\text { demand }\end{array}$ \\
\hline (3) Major impact stimul & $\begin{array}{l}\text { Volume and } \\
\text { variety } \\
\text { fluctuations in } \\
\text { demand }\end{array}$ & $\begin{array}{l}\text { Line } \\
\text { breakdown, } \\
\text { inadequate } \\
\text { delivery } \\
\text { capacity }\end{array}$ & $\begin{array}{l}\text { Volume and } \\
\text { variety } \\
\text { fluctuations in } \\
\text { demand with } \\
\text { unpredicted } \\
\text { specifications }\end{array}$ & $\begin{array}{l}\text { Unpredicted } \\
\text { specifications } \\
\text { and non- } \\
\text { product } \\
\text { repeatability }\end{array}$ \\
\hline (4) Awareness & $\begin{array}{l}\text { Fluctuating } \\
\text { demand }\end{array}$ & $\begin{array}{l}\text { Stock } \\
\text { availability at } \\
\text { all times, state } \\
\text { of the delivery } \\
\text { system }\end{array}$ & $\begin{array}{l}\text { Fluctuating } \\
\text { demand, } \\
\text { realising } \\
\text { customers } \\
\text { orders in real- } \\
\text { time }\end{array}$ & $\begin{array}{l}\text { Design and } \\
\text { quotation } \\
\text { stages, } \\
\text { producing to } \\
\text { customer } \\
\text { specifications } \\
\quad \text { (continued) }\end{array}$ \\
\hline
\end{tabular}




\begin{tabular}{|c|c|c|c|c|}
\hline Characteristics & Group I & Group II & Group III & Group IV \\
\hline (5) Capabilities & $\begin{array}{l}\text { Adjust daily } \\
\text { plan, rotate } \\
\text { capacity and } \\
\text { workforce, keep } \\
\text { safety stock }\end{array}$ & $\begin{array}{l}\text { Rotate stock to } \\
\text { where it is } \\
\text { needed, truck } \\
\text { scheduling }\end{array}$ & $\begin{array}{l}\text { Real-time } \\
\text { scheduling, } \\
\text { effective } \\
\text { capacity } \\
\text { planning for the } \\
\text { whole plant, } \\
\text { customer } \\
\text { relationships }\end{array}$ & $\begin{array}{l}\text { Quick } \\
\text { quotation, co- } \\
\text { ordination } \\
\text { between project } \\
\text { departments } \\
\text { and production } \\
\text { department }\end{array}$ \\
\hline Table 2 cor & $\begin{array}{l}\text { Be able to } \\
\text { supply } \\
\text { fluctuating } \\
\text { demands }\end{array}$ & $\begin{array}{l}\text { Be able to } \\
\text { supply } \\
\text { customer at all } \\
\text { times }\end{array}$ & $\begin{array}{l}\text { Be able to } \\
\text { supply } \\
\text { fluctuating } \\
\text { demands in } \\
\text { both volume } \\
\text { and variety } \\
\text { specifications }\end{array}$ & $\begin{array}{l}\text { Be able to } \\
\text { supply } \\
\text { customers with } \\
\text { the precise } \\
\text { specification } \\
\text { they need on } \\
\text { time }\end{array}$ \\
\hline
\end{tabular}

the groups. A corollary to this is that companies in each group may require intervention in different areas to improve responsiveness of the order fulfilment process. For instance, the companies in group I may achieve improved responsiveness by effective adjustments in production plans in order to absorb the fluctuation in demand. In group II companies, safety stock and delivery systems may be major factors in achieving responsiveness. In group III companies, raw material provision and shop floor performance may be important for responding to customised demand. For the group IV companies, emphasis may be needed on efficient design and quotation systems as well as efficient project-type manufacture.

\section{Discussion}

In this section we develop the observations and analysis in two ways. First, the field and case study evidence is used to develop more precise and informed definitions and descriptions of each of components of responsiveness. Second we propose a generic framework for understanding and gaining insight into responsiveness in manufacturing enterprises.

\section{Responsiveness components}

Stimuli: these are the factors, events and issues that have, or could have an impact on system activities and expected or desired goals. Stimuli are the major factors driving any firm to respond and hence provide the impetus to develop responsiveness capabilities. Stimuli include all the typical disturbances associated with manufacturing systems. However the term disturbance tends to have negative and narrow connotations whereas the term stimuli implies a more neutral value judgement. Thus a small order for a special product which is difficult to manufacture might be viewed negatively as a disturbance but may also be viewed positively as a future opportunity to enter a new market. 
Kritchanchai, D., \& MacCarthy, B. L. (1999). Responsiveness of the order fulfilment process.

International Journal of Operations \& Production Management, 19(8), 812-833.

Stimuli will vary depending on the environment, the nature of the industry and its products, and operational characteristics. Within any particular environment a number of different stimuli may occur, having different impacts with respect to a firm's goals and driving it to have appropriate responsiveness capabilities in each case. However, stimuli will emanate from common sources in any business environment. Thus many stimuli will emanate from the nature of demand, demand variation and individual customer needs. Constraints and conditions associated with customers and demand will also be a factor. Stimuli encompass uncertainties and changes within or outside the firm with respect to operational problems such as machine breakdowns, errors, raw material shortages and unavailability of workers and external factors such as legislation and suppliers, competitors and their activities, market conditions and the needs of the market. Examples of most of these stimuli were apparent in the case study companies.

Awareness: this refers to a firm's knowledge and recognition of stimuli that occur or may occur, and the preparation and responses necessary to address them, whether they emanate from customer needs, environmental uncertainties, competitors or market conditions. Awareness is a fairly soft concept and is often detected by the presence of specific capabilities, discussed below. In the case study companies examples of practices demonstrating awareness include: keeping safety stock, calculating machine breakdown likelihood, forecasting materials and labour requirements, and holding excess machine capacity.

Capabilities: this component refers to the activities and processes that enable a company to respond appropriately to the stimuli. By capability in this context we mean more than just a technical ability to respond. Capability requires the existence of knowledge and decision making structures necessary to use or deploy basic abilities. Thus it implies a systems or a business process viewpoint. Capabilities should match the relevant stimuli. Examples of the practices from the case studies that demonstrated capabilities included adjusting daily production plans to respond to customer demand fluctuations, rotating stock from elsewhere to respond to shortage of inventory, having good relationships with suppliers to cope with urgent, unusual or unpredicted requirements.

Goals: responsiveness is goal driven. However, not all firms will be driven to respond to every stimulus at a similar level and the same goals may not be appropriate in different environments. Firms decide their goals within the context of their business and operational environment. In addressing this issue we highlight the need for clarity and commitment to both achieving stated goals and maintaining a desired level of performance. In focusing on the order fulfilment process the generic goal is to meet the demands placed on the manufacturing business. However the case study companies demonstrated different approaches to achieving this generic goal. For example, the beverage company tended to employ the policy of making today what was sold yesterday, in order to fulfil customer orders by maintaining their 'on-the-shelf' standard products in terms of the 
Kritchanchai, D., \& MacCarthy, B. L. (1999). Responsiveness of the order fulfilment process.

International Journal of Operations \& Production Management, 19(8), 812-833.

volume and variety that customers need. The gas company viewed transportation as its business. It tended to achieve its goals through a well-developed delivery system. The specialised machinery company achieved its goals by fulfilling customer orders with the exact specifications required and on time.

\section{A generic framework for responsiveness}

Our discussion of the components of responsiveness implies that a particular firm is subject to specific stimuli that necessitate specific responses and that different capabilities to respond are necessary depending on the nature of the firm and its business environment. This raises the question of a company's overall approach to responsiveness. What sets the strategic direction and constraints in each firm that then impact on the level of responsiveness?

From our studies it is clear that companies tend to be responsive with respect to their strategic directions and the key issues are then to determine the appropriate ways to respond and the appropriate levels of responsiveness. Essentially there are three fundamental decisions: are we going to respond and, if so, how and at what level should we respond? It is useful in this context to view responsiveness from two perspectives - business strategy and operations strategy. Figure 1 illustrates our conceptual framework for responsiveness in a manufacturing organisation.

Interactions between the strategic an operational level may result in a range of different responsiveness directions and approaches. At the strategic level, responsiveness directions may be influenced by the nature of the industry, the type of market served, its size and maturity. Some companies may have a strategy to intentionally limit their responsiveness. In any case the strategic level sets the constraints for responsiveness at the operational level where approaches for achieving responsiveness must take into account operational characteristics.

This generic framework provides a viewpoint based on the four components stimuli, awareness, capabilities and goals. It can provide a basis to investigate and assess aspects of responsiveness in a company. Questions indicated by the framework include:

- Is a company aware of :

- What their stimuli are within their business environment?

- What level of impact their stimuli have on goals?

- What capabilities should be provided to enable appropriate responses?

We note that awareness in a firm can often be assessed through the capabilities that they provide, or intend to develop, reflecting recognition of the impact of particular stimuli.

- How well do the capabilities that exist enable satisfactory responses to stimuli? This may be viewed as a subjective assessment.

- How well does a company achieve its goals? This may be viewed as an objective assessment, looking at overall performance. 


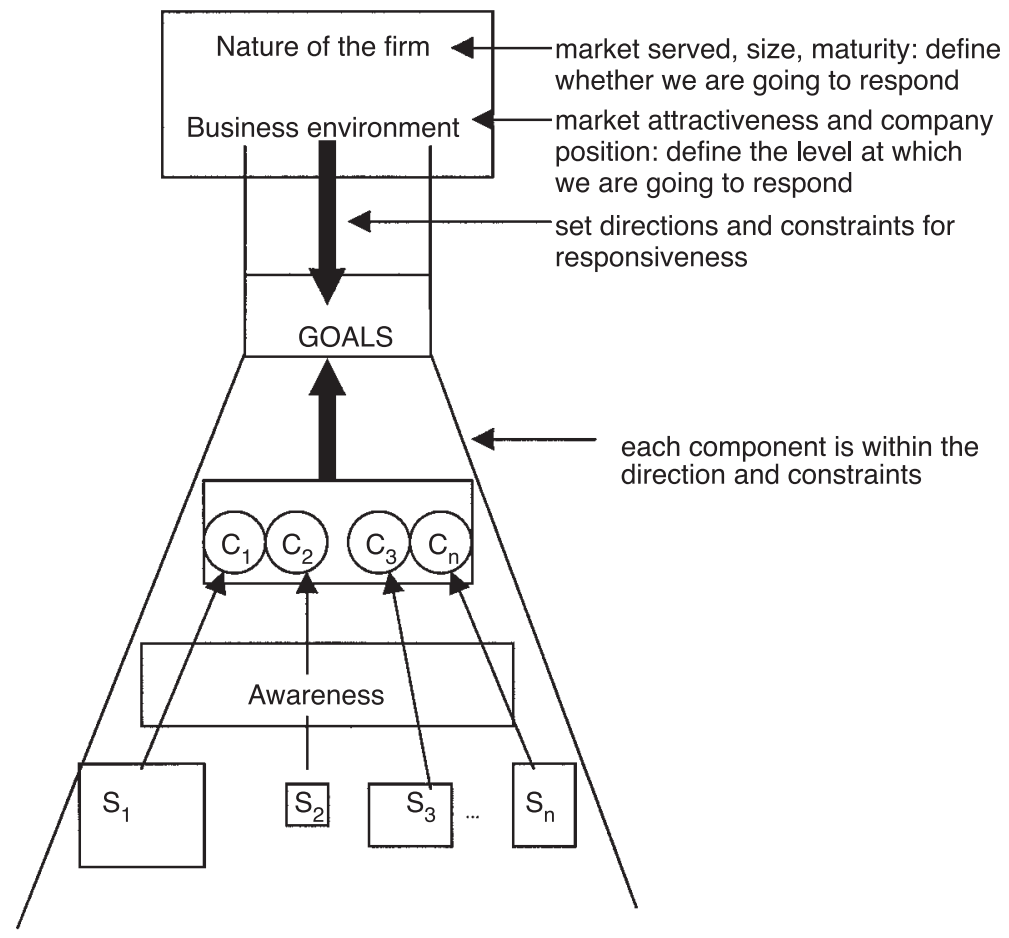

$S_{1} \ldots S_{n}$ represent different stimuli with varying levels of impact. The stimuli occur within the directions set at a firm's strategic level; thus they are different from other firms' directions. $C_{1} \ldots C_{n}$ indicate the capabilities that match the particular stimuli to respond to achieve desired goals.

Figure 1. Responsiveness framework

\section{Further research}

The work reported here is based on field studies, supporting cases and the literature on responsiveness and related areas such as time-based competition. Field research in the literature specifically focusing on responsiveness has been fairly limited and further field-based research is recommended. Clearly more fieldwork may be beneficial in testing, validating and extending the research presented here. The observations and analysis presented in this paper point to hypotheses, which should be tested more widely. First we recommend that the similarities and differences with respect to the components of responsiveness and the characteristics of order fulfilment processes be investigated in other field studies. Second we recommend that the grouping of companies based on the characteristics of their order fulfilment processes be investigated more widely. A validated and robust classification of companies based on the characteristics of their order fulfilment processes has the potential to develop intervention strategies of specific benefit to particular sectors. 
Kritchanchai, D., \& MacCarthy, B. L. (1999). Responsiveness of the order fulfilment process.

International Journal of Operations \& Production Management, 19(8), 812-833.

A fruitful area for further investigation is likely to be the assessment and measurement of responsiveness along with the development of appropriate intervention strategies. There is also much room for modelling, analysis and simulation of responsiveness in the order fulfilment process, evaluating qualitatively and quantitatively the effects of operating parameters in different environments. The authors' current work is addressing both fieldwork and analytical issues.

\section{Conclusions}

In this paper we have developed a view of responsiveness particularly related to order fulfilment processes, based on findings from a fieldwork study in Thailand and supported by evidence from companies in the UK and case studies in the literature. The field and literature evidence has been analysed and companies have been partitioned into four groups based on similarities and differences. In addition we have analysed the generic factors that place companies into specific groups and that influence the need for, and approach to responsiveness. Four components of responsiveness that emerge from the literature - stimuli, awareness, capabilities and goals - have been defined and described. A generic framework for responsiveness has been developed that incorporates both strategic and operational viewpoints based around the four components of responsiveness. We believe that the approach presented here makes the concept of responsiveness more visible, more tangible and more usable. Further work is proposed to extend the research and develop responsiveness measures and intervention strategies appropriate for particular environments.

\section{References}

Azzone, G. and Masella, C. (1991), Design of performance measures for time based companies, International Journal of Operations and Production Management, Vol. 11 No. 3, pp. 77-85.

Barclay, I., Poolton, J. and Dann, Z. (1996), Improving competitive responsiveness via the virtual environment, IEEE IEMC 96, pp. 52-62.

Bozart, C. and Chapman, S. (1996), A contingency view of time-based competition for manufacturers, International Journal of Operations and Production Management, Vol. 16 No. 6, pp. 56-67.

Daugherty, P.J. and Pitman, P.H. (1995), Utilisation of time based strategies: creating distribution flexibility/responsiveness, International Journal of Operations and Production Management, Vol. 15 No. 2, pp. 54-60.

Easterby, S.M., Thorpe, R. and Lowe, A. (1991), Management Research, Sage Publications, London. 
Kritchanchai, D., \& MacCarthy, B. L. (1999). Responsiveness of the order fulfilment process.

International Journal of Operations \& Production Management, 19(8), 812-833.

Frey, E. (1988), "The evolution of performance measurement", Industrial Management, September-October 1988, pp. 9-12.

Fry, T. (1990), "Controlling input: the real key to shorter lead times", The International Journal of Logistics Management, Vol. 1 No. 1, pp. 7-12.

MacCarthy, B.L. and McFarlane, D. (Eds) (1998), Proceedings of the IEE Workshop on Responsiveness in Manufacturing, Savoy Place, London, 23 February 1998, IEE Digest 98/213, IEE Publications, London.

Noori H. and Radford, R. (1995), Production and Operations Management: Total Quality and Responsiveness, McGraw-Hill, New York, NY.

Shapiro, B.P. Rangan, V.K. and Sviokla, J.J. (1992), 'Staple yourself to an order', Harvard Business Review, July-August 1992, pp. 113-22.

Sin Hoon Hum and Hoon Hong Sim (1996), "Time based competition: literature review and implication for modelling", International Journal of Operations and Production Management, Vol. 16 No. 1, pp. 75-90.

Slack N., Chambers, S., Harland, C., Harrison, A. and Johnston, R. (1998), Operations Management, 4th ed., Pitman Publishing, London.

Stalk, G. Jr (1988), Time \pm the next source of competitive advantage, Harvard Business Review, Vol. 66 No. 4, pp. 41-51.

Stalk, G. and Hout, T.M. (1990), Competing Against Time: How Time Based Competition is Reshaping Global Markets, Free Press, New York, NY.

Upton, D.M. (1994), The management of manufacturing flexibility, California Management Review, Vol. 36 No. 2, pp. $72-89$.

Van Donk, D.P. (1998), Competitive response in the food processing industries: from make to stock to make to order, in Coughlan, P., Drumgoole, T. and Peppard, J. (Eds), Proceedings of the 5 th International Conference of the European Operations Management Association, pp. 153-8. 